\title{
Three different Cherry Orchards, three different worlds: Chekhov at the BBC, 1962-1981
}

Article

Accepted Version

Smart, B. (2014) Three different Cherry Orchards, three different worlds: Chekhov at the BBC, 1962-1981. Critical Studies in Television, 9 (3). pp. 65-76. ISSN 1749-6020 doi: https://doi.org/10.7227/CST.9.3.7 Available at https://centaur.reading.ac.uk/71897/

It is advisable to refer to the publisher's version if you intend to cite from the work. See Guidance on citing.

Published version at: https://doi.org/10.7227/CST.9.3.7

To link to this article DOI: http://dx.doi.org/10.7227/CST.9.3.7

Publisher: Manchester University Press

All outputs in CentAUR are protected by Intellectual Property Rights law, including copyright law. Copyright and IPR is retained by the creators or other copyright holders. Terms and conditions for use of this material are defined in the End User Agreement.

$\underline{\text { www.reading.ac.uk/centaur }}$

\section{CentAUR}


Central Archive at the University of Reading

Reading's research outputs online 
Three different Cherry Orchards, three different worlds: Chekhov at the BBC, 1962-1981.

\section{Billy Smart}

Abstract: Unlike the theatre, there is no established tradition of plays being revived (new productions made from existing scripts) on television. The only instance of this mode of production in Britain has been the regular adaptation of classic theatrical plays. The existence of three separate BBC versions of Chekhov's The Cherry Orchard $(1962,1971,1981)$ creates a rare opportunity to trace developing styles of direction and performance in studio television drama through three different interpretations of the same scene. Through close analysis of The Cherry Orchard, I outline the aesthetic and technological development of television drama itself over twenty years.

Keywords: The Cherry Orchard, Anton Chekhov, BBC, Richard Eyre, Trevor Griffiths, television adaptation and studio space. 
This article intends to demonstrate the unique value that study of the classic theatrical adaptation can hold for television studies, and add to the small corpus of writing on the television theatrical adaptation. ${ }^{i}$ A major difference between theatre and television is that there is little tradition of drama made for TV being revived. Repeated, certainly, but not revival in the theatrical sense of the same script being reinterpreted. While television retells classic stories from literature and reboots old programmes, one thing that it does not do is make new productions from existing scripts, as continually happens in the theatrical repertoryii. While literary classics such as Great Expectations or Jane Eyre have been adapted regularly for British television, ${ }^{\text {iii }}$ each new production has been a reimagining of the source novel through an entirely new screenplay, unlike theatrical adaptations, which generally closely followed the same settings, form, structure and dialogue created by the original playwright. Study of the TV stage adaptation reveals no intermediary screenwriter adaptor figures of the stature of Andrew Davies or John Mortimer.

The only examples that we can refer to of dramas being revived in British television are those adaptations of classic plays broadcast in the twentieth century, which regularly featured in the schedule in series such as Sunday Night Theatre (BBC Television, 1950-9), Play of the Month (BBC1, 1965-83), Theatre Night (BBC2, 1985-1990) and Performance (BBC2, 1991-1998). 
The production and archival survival of three separate BBC productions of Anton Chekhov's 1904 play The Cherry Orchard in the sixties, seventies and eighties ${ }^{\text {iv }}$ creates a rare opportunity to trace developing styles of direction and performance in studio television drama through different interpretations of the same scene. In this article I shall discuss the diverse dramatic effects achieved by the three productions in one brief moment towards the end of the play (Act IV), outlining how creative decisions (set design, directorial selection of shots and performance style) determined the different effect of each version upon the viewer. I will offer a textual analysis considering how the scene is realised and enacted for each version in chronological sequence, prefacing each interpretation with an outline of its production context, drawing conclusions as to how the emotional effect of each scene was determined by underlying technological and production circumstances ${ }^{v}$

The moment in the play occurs while the Ranevsky family are in the final stages of leaving their family estate (the orchard) for good, collecting cases and waiting for a cab to take them to the station. Left alone together for a few snatched minutes in an empty nursery room Lopakhin (the merchant who has bought the estate) finally and definitively fails to propose to Varya (the adopted daughter of Madam Ranevsky), despite both characters wishing and expecting this to 
happen: Varya cannot find something that she has packed, Lopakhin talks about the weather and is then called away.

Although Chekhov's naturalistic dramaturgy can seem inconsequential and loosely structured this scene is a good example of how it is actually very precisely plotted and controlled, working towards a powerful, cumulative effect. Even when experienced in disappointing productions, I always find this scene highly painful and affecting to watch in performance. Until I read David Mamet's 1986

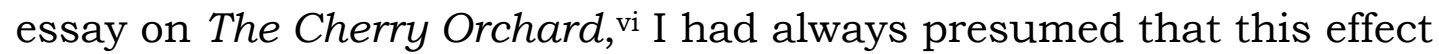
was only because of the inherent emotional interest of watching a missed opportunity being enacted right before my eyes. Mamet argues that the entire play pivots around all the characters' expectation that Lopakhin and Varya will marry, meaning in turn that the family will stay in their home. Were Lopakhin to propose in Act One, then The Cherry Orchard could not exist as a play:

Why, hell. If I wanted to save $m y$ cherry orchard, and $m y$ adopted daughter was in love (and we are told that her affections are by no means abhorrent to their recipient) with the richest man in town, what would $I$ do? What would you do? It's the easiest way out, the play ends in a half hour, and everybody gets to go home early.vii

Act Four is the last possible moment that the proposal can happen. If Lopakhin acts at this moment then Madam Ranevsky can still return to the cherry orchard, making his final failure to do so the most 
crucial moment of the drama. The scene is vital to the play, but the audience understands the reasons for its centrality implicitly rather than explicitly.

\section{The Cherry Orchard (BBC Television, 13 April 1962)}

The 1962 BBC Cherry Orchard was a transfer of a current Royal Shakespeare Company production (performed at the Royal Shakespeare Theatre, Stratford-Upon-Avon and the Aldwych Theatre, London) directed by the veteran Michael Saint-Denis who, as founder of the London Theatre Studio, was renowned for his sympathetic understanding of actors. The production was remounted for the BBC Television Centre studio by Michael Elliott, who had made a name for himself as a young theatre director who also regularly worked for television, most famously with his 1959 production of Ibsen's rarelyperformed verse drama Brand starring Patrick McGoohan. viii The Cherry Orchard was the first time that an RSC production had been broadcast on television, and was a highly prestigious programme for the BBC. As one might expect, this version is cast to the very highest level, starring Peggy Ashcroft (Ranevsky), John Gielgud (Gaev), George Murcell (Lopakhin) and Dorothy Tutin (Varya), also featuring young actors of exceptional promise in smaller roles, including Ian Holm (Trofimov) and Judi Dench (Anya).

Contemporary commentary on the Aldwych staging identifies a tension between conflicting interpretations of Chekhov within the production, the first major revival of The Cherry Orchard in London 
since the 1958 visit of the Moscow Arts Theatre to Sadlers Wells Theatre, playing a repertory of Chekhov productions. The Russians' interpretation of the plays was praised for its sense of emotional clarity and finely realised mise-en-scene, illustrating how "Chekhov's organic use of the stage, including spatial build-up of dynamic movement and use of props (was) every bit as important as the dialogue, and confirms that if Stanislavsky had not existed it would have been necessary to invent him."ix The Times' anonymous critic of the RSC version suggests that the production was a halfway house between the dominant English interpretation of Chekhov since the 1930s marked by "the taint of sentimentality", and that of the Russians, who had given a "purposeful" interpretation, emanating "confidence" and a "more virile approach to the characters" that brought "us nearer to the real meaning of the plays", with "SaintDenis in this production seek(ing) a rather uneasy compromise between the old way and the new".x The critic regretted some of the expected effects that were lost in this move:

The great merit of the old pattern of playing, which has yielded many fine and moving productions (...) (was that it demonstrated how) Each character was regarded as an island, and each actor and actress stood ready at any moment to draw attention to the particular island on which he or she stood (...) What were considered the poetic values depended upon this effect.xi 
The writer singled out the moment of the failed proposal as one incidence when the merits of the old pattern were maintained: "some of the inadequately patterned bits and pieces are in themselves disappointing, others are extremely telling. Miss Dorothy Tutin's scene in which Varya's hoped-for proposal is burked for good and all is exquisitely staged."xii This tension between two different styles of interpretation can also be read into the $\mathrm{BBC}$ version of the production, which combines 'organic' staging and 'sentimental' performance.

The 1961 staging is set in a much larger room than subsequent versions, a three-sided set that belies the production's proscenium arch theatrical origins. The expansive setting is utilised by both performers walking through the scene, continually moving towards and away from the door, windows and middle of the room. Both characters' inability to communicate is demonstrated by the frequency with which they walk away from each other in order to look out of the window, crouch on the floor to handle a blanket, and ultimately for Lopakhin to run out of the room. With one or either character in continual motion, at no point in this scene are both placed together and seen in the same scale, with one or other (generally Varya) always in the foreground. Eye contact between the couple is minimal in this version, with Lophakin electing to look out of the window instead of at Varya.

Three cameras are used to record this scene, consisting of 15 shots. Michael Elliott generally avoids quick cutting, but implicates the 
viewer in the action through following the rather giddy camera mobility, swooping through the room and revolving around the figure of Varya. The frame of the shot is usually in motion rather than static, with the two performers either walking into the focus or the camera pulling towards or away from them.

Dorothy Tutin's performance of these exchanges privileges the viewer rather than Lophakhin as witness to Varya's internal thoughts and feelings. With Varya facing the camera in the foreground and Lopakhin far in the background the performer often plays the line (deriving the maximum poignant resonance from the dialogue, "Life has come to an end in this room") rather than the scene.xiii This register, combined with Elliot's cameras' focus on the performer, is a perfect example of television technique accentuating the traditional interpretation of Chekhov approved by the Times' critic, spotlighting the sufferings of the individual character in isolation. This poetic effect reaches a peak at the climax of the encounter in this version in which, once left alone, Varya outstretches her arms in wide shot, the camera zooms into a close-up that stops at the moment when she starts to cry, raises her hand to cover her face and falls to the floor, cutting to a different camera to show her descent in wide-shot.

In combination with a heightened acting register this continual motion gives the scene a rather operatic, epic, quality that is perhaps not in keeping with the scene's ostensible bathos. One television critic disapproved of this technique: 
I wasn't keen on the restless use of the zoom, rushing from spacious architectural wide-angle shots to portrait focus; the close-ups damaged the 'atmosphere' like thunder-claps. xiv

The 1962 version reveals a tension between theatrical and televisual styles of presentation, with the roaming direction belonging to Television Centre while the acting remains in the Aldwych Theatre. Performances in this version of the naturalist classic cannot be described as realistic, with actors concentrating on conveying the subtext of lost opportunities, rather than the surface activity of packing and inconsequential small talk. This may have seemed less jarring on stage, because there is a strong sense of a missing third party of a theatrical audience in this scene, with its extensive wistful and poignant looking-outs into the middle distance.

\section{Play of the Month: The Cherry Orchard (BBC1, 19 December}

\section{1)}

The 1971 production was made for television, appearing in the Sunday night BBC1 Play of the Month slot, the regular site for classic theatre plays in the 1970s. ${ }^{\mathrm{xv}}$ Cedric Messina, who also produced the series, directed this version. Messina is the single dominant figure of the genre, being responsible for hundreds of adaptations made by the BBC between the sixties and eighties. Messina's approach to Play of the Month can be likened to that of a West End theatrical impresario, concentrating upon productions with a highly decorative mise-enscene of beautiful sets and costumes (ideal for realisation in the then- 
new high-definition 625-line colour television technology), peopled by appealing companies of stars. The Cherry Orchard casting ably illustrates these priorities, featuring Celia Johnson (Ranevsky), Charles Gray (Gaev), Gemma Jones (Varya) and, particularly, Edward Woodward, most famous at the time for the phenomenally popular ITV spy series Callan (ABC/Thames 1967-72, ATV 1981), as Lopakhin.

Present-day viewers face an insurmountable problem in fully appreciating how Messina's decorative aesthetic functioned in The Cherry Orchard, which only survives as a $16 \mathrm{~mm}$ black-and-white telecine print, making it looks like a B-picture from the 1930s rather than the sharp colourful image of the 2" videotape originally broadcast in 1971.xvi The viewer can, however, peer through the murk to gain some idea of the tremendous attention paid to beautiful sets in this version, which occurs in far more rooms than would be practicable for any stage production of The Cherry Orchard.xvii The elaborate detail was noticed by contributors to the 1971 BBC Audience Research Report who, while commending the costumes and settings, "claimed that the interiors of Madame Ranevsky's house 'seemed to make architecture nonsense' (...) feeling "it a pity that so much care and talent should have been spent on what was, to them, a dull play".xviii

Although made nine years later, the 1971 version of this scene seems visually flatter and less ambitious than Elliot's interpretation, with nothing occurring in either camera movement or shot selection to distinguish it from other television dramas of the time. Between Mme. 
Ranevsky leaving and returning, the scene is shown in twenty shots. After a dramatically unnecessary cutaway to the landing (the showman Messina was always keen to show off how many sets had been built for his productions) three cameras are used, one for twoshots of the characters in the space of the cramped room, the other two for close-ups of Lopakhin and Varya. The set-up is conventional, with nothing disruptive in the rhythm of the cameras' mixing occurring to surprise the viewer. In this version Varya's final isolation is entirely conveyed through a short, supressed, keening bark of pain from Gemma Jones, with the camera remaining static. This plain style makes following the development and nuances of the scene easy for the audience. In this televisually conventional reading of the scene the camera is not so much commenting upon the action, but relaying it to the viewer.

One major development between 1962 and 1971 is in the positioning of the acting, with Lopakhin and Varya both standing still during the exchange. Without wistful looks into the middle distance, there is much less sense of a performance to camera, and a greater awareness that the characters are exclusively responding to each other and to the environment of the room, rather than to the unseen audience. This operates through a pattern of one character looking towards the other, who then discovers some competing distraction (a handkerchief or packing case) to concentrate their attention upon instead. This form of performance, presented to the viewer in close-up scrutiny, 
lacks the operatic register of the 1962 version but, in a different way, also cannot be described as entirely realistic, magnifying performers' use of tics and odd inflections. The form and rhythm of this interpretation works as much to highlight the decisions made by actors as those by characters, particularly for viewers with prior knowledge of Edward Woodward's other roles (who, thanks to Messina's star casting, must have constituted the majority of the audience). Critical coverage concentrated on this aspect of the production:

Callan in Chekhov? You must be joking. Certainly Edward Woodward has identified himself so much on television with Britain's seedy modern agent that it seemed foolhardy to cast him last night as a wealthy Russian in a period piece. In the event, however, the off-key voice and the rasping manner transferred well to the self-made Lopakhin in this classic drama.xix

One advantage of the close-up presentation and back-and-forth camera rhythm following the dialogue of this interpretation of the scene is that it creates a sense of how the characters already know each other and how this friendship might operate. In the exchange of inconsequential lines (Lopakhin: "There's three degrees of frost" Varya: "I hadn't looked. Besides our thermometer's broken") a complex series of looks, turns away, smiles and laughter-to-oneself is exchanged between the two performers. This exchange conveys the characters' 
understanding of each other, their acknowledgement of the moment passing, and the specific awareness of weirdness of the occasion that one can feel at times of extraordinary personal significance. This unexpected and subtle, unsentimental, moment demonstrates some advantages of the Cedric Messina 'house style' of casting familiar television performers and relaying performances through conventional shot selection. Such experienced TV actors as Edward Woodward and Gemma Jones had acquired sufficient instinctive understanding of studio cameras' ability to pick up small details and nuances of their performances, and the easy-to-follow rhythm of shot selection meant that attentive viewers could receive these subtleties.

\section{The Cherry Orchard (BBC1, 12 October 1981)}

If the 1971 production is representative of television stage adaptation, the 1981 version is so anomalous as to be unique, being recorded in the studio, but on lightweight Outside Broadcast equipment. The play came to be shot in such unorthodox circumstances due to the determination of Richard Eyre, staff producer (and occasional director) for Play For Today (BBC1, 1970-84), to mount a production. Eyre's background was in theatre not television, most notably as Artistic Director of the Nottingham Playhouse where his productions of new plays by Howard Brenton, Trevor Griffiths and David Hare had attracted much attention and comment. As all three playwrights had concurrent television and stage careers, Eyre was considered suitably qualified to produce the BBC's most high-profile series of original 
television plays, despite the move across media. ${ }^{\mathrm{xx}}$ As part of his first Play For Today season, Eyre had directed an adaptation of Griffiths' play Comedians, one of the directorial successes of his period at Nottingham Playhouse.

Keen to continue this collaboration between director and writer, the two men looked to produce an adaptation of their 1977 Nottingham Chekhov adaptation (which had only run for four weeks) for a wider television audience. Because of the play's non-contemporary origin, it lay beyond the remit of Play For Today, and slots could not be found for recording at the $\mathrm{BBC}$, the established Play of the Month and the $B B C$ Television Shakespeare (BBC2, 1978-85) series taking precedence. A year later, the play was recorded under a slot booked for Play For Today (although not transmitted under that title), with the concomitant smaller budget and time available for a contemporary single play.xxi Consequently, the play was shot with two cameras on OB equipment, an approach that gives this Cherry Orchard a very different feel to other adaptations, with flexible camera movement creating more tightly arranged and choreographed scenes than had been made by mixing between multiple cameras.

Eyre was pleased with the different working practices created by the OB conditions, chiming with experience and thoughts about television narrative through shooting Play For Today productions on film, and a scepticism about conventional videotaped studio drama, with its lack of opportunity for precise cutting.xxii The more limited camera 
resources would mean that The Cherry Orchard would have to be meticulously planned out in advance:

Restricted studio time would still remain a central problem but with full rehearsal and detailed preparation, the project did seem feasible. With the committed cooperation of [senior cameraman] Geoff Feld and lighting designer Howard King, the technique was made to work. Each shot was framed and lit individually, mostly using just a single camera, and these brief sequences were then edited together in the post-production process. ${ }^{x x i i i}$

This description gives a slightly misleading impression of how the narrative of The Cherry Orchard is arranged. Instead of a mosaic of brief fragments, most shots are very long and uninterrupted, with occasional cutaways of close-ups of faces in reaction or speaking. These lengthy shots are unlike previous studio productions in part because the lightness and mobility of the OB equipment allowed for cameras to operate within a four walled set, as in the first act where the camera moves into the house through the door and then follows events by crossing into the main room. This sense of the interiors of the house as an actual lived space is augmented by the different texture of OB videotape stock, which has a softer grain than conventional studio videotape, feeling more like 16-millimeter film, and therefore bearing close affinities to the viewer's expectations of filmed drama. Although the sense of vividness and contrast on 
familiar VT is consequently sacrificed, the lighting in The Cherry Orchard is softer than in other adaptations, creating a sense of reality and actuality of location for the viewer, a useful emphasis in a play about the sale of a property.

Eyre saw his production as a recovery of the television adaptation from years of accreted standard practice, a direct parallel with Griffiths' recovery of Chekhov's text, both reinventions challenging established notions of how adaptation could be achieved. Griffiths saw The Cherry Orchard, with its accrued cultural status as a study of whimsy, poignancy, eccentricity and theatricality, as a play that the viewer could read through a series of meanings and intentions to reveal a concrete study in materialism, class, property and the means of production, xxiv a reading supported by Raymond Williams' analysis of conventionally staged Chekhov being seen by audiences as supporting a view of "how life is" naturalist presentation of reality creating an ideological structure of feeling:xxv

I did Cherry Orchard because I felt that its meanings had been seriously betrayed, almost consciously betrayed, over forty or fifty years of theatre practice in this country. xxvi

With this intention, Griffiths reworked the play in two ways. The first way was through reducing exposition, informed by seventy-three subsequent years of cinematic storytelling after Chekhov wrote The 
Cherry Orchard, allowing characters to explain their feelings though fractured half-expressed thoughts rather than in formal sentences, $x$ xvii an approach supported on television by Eyre's ability to use cinematic close-ups of characters in reflection, allowing the viewer a sense of insight into characters' interior lives.

The second reworking was to adjust the hierarchical structure of the play's casting, Eyre emphasising in rehearsal that The Cherry Orchard depicted the spectrum of society in twelve characters of equal importance.xxvii This intention can perhaps be made clearer in a television staging of a play than in a theatrical one due to the director's control over the selection of shots seen by the viewer. Eyre's Cherry Orchard emphasises the collective to an unusual, an effect achieved through lengthy takes of long shots of multiple characters entering and exiting rooms and interacting. Within a structure that emphasises the company in most shots, infrequent close-ups edited filmically into the action bear much more weight, and appear to carry more directorial intention, than in a conventional camera rhythm of establishing shots, two shots, reaction shots, etc.

The vérité qualities of Outside Broadcast equipment make the room appear a much more real space in this version than others. This is the only version of the scene in which the viewer can hear as well as see the room: the floorboards echo any movement across them (more so than in Acts I and II, when the room was carpeted and furnished) and voices become less resonant when spoken in a muffled, enclosed 
space. This aural placement of the figures within a precisely defined space, in which it is possible to hear characters turn the handle of a door and walk across the room, locates the viewer more in the immediate moment of the encounter.

The enforced limitations of the single camera create a radically different version of this scene, quieter and much more concentrated. The moment is conveyed in just three shots; a wide shot of Lopakhin (Bill Paterson) and Varya (Harriet Walter) in the room, a two shot of the two failing to connect, and a close-up of Varya alone - the narrative essence of the scene in three steps.

Losing the sense of camera motion or cutting encourages the viewer to concentrate upon the minutiae of Lopakhin and Varya's behaviour towards each other. When initially viewed in long shot, the couple's actions are framed within the context of the room, allowing the performers' to physically convey their characters' failure to make contact by looking at or approaching each other through their whole bodies, such as when Lopakhin delays walking up to Varya by moving his weight from one leg to another instead.

When Lopakhin does eventually approach Varya it is under the pretext of looking out of the window and the entire second shot is played with Lopakhin in profile and Vara facing the camera, directing the viewer's attention towards Varya's responses, making the scene uncomfortable and upsetting to watch. The precise moment when the encounter is doomed to failure is signalled to the viewer, with Varya 
failing to return Lopakhin's gaze, instead looking at the packing cases. Varya acknowledges this by closing her eyes on "life in this house is over" (rendered by Griffiths as the less portentous "there's nothing else here, now"), and when she opens her eyes again looking at Lopakhin to assess what she has lost. Lopakhin and Varya are placed shoulder to shoulder to each other in this section, and this sense of closeness in their mutual unspoken acknowledgement of an opportunity passing allows the viewer to gain a strong sense of how the pair might have been as a married couple, evoking an acute sense of loss and identification.

\section{Conclusion}

The 1981 production can be read as being a response to the techniques utilized in the two earlier versions, with Richard Eyre seeing his production as a recovery of the television adaptation from years of accreted standard practice, this recovery being a direct parallel with Griffiths' recovery of Chekhov's text, both reinventions challenging established notions of how adaptation could be achieved.

The example of these three productions of The Cherry Orchard has demonstrated something of the unique usefulness and significance that the TV stage adaptation can hold for television studies. Through comparison of the same scene over three productions we can trace something of the development of television drama itself: How performance and direction in the early sixties sometimes struggled to adapt theatrical technique into something more suited for television, 
the development of a conventional 'television style' form of multi-

camera studio drama production, and, in the innovative and ahead-ofits-time Griffiths-Eyre production the development of a single camera form, one that could still apply to contemporary television production technology, and suggests the continuing potential of the theatrical adaptation for TV.

\section{Acknowledgements}

This article is one of the outcomes of the research project "Spaces of Television: Production, Site and Style", funded by the Arts \& Humanities Research Council from 2010-15.

\footnotetext{
${ }^{i}$ Few collections of writing specifically about the theatrical television adaptation have been published. The most useful from a television studies perspective is Ridgman, Jeremy (ed), Boxed Sets: Television Representations of Theatre, Luton: University of Luton Press, 1998, a collection of articles that document the development of the stage adaptation as a genre and address wider questions of television representations of theatricality through discussion of arts documentaries and general questions of performance.
}

ii There was a tradition of unaltered scripts being periodically revived in the early repertory of British television drama, a practice that died out in the 1950s.

iii Great Expectations has thus far been adapted for British television six times (1959, 1967, 1981, 1991, 1999, 2011 - all BBC except 1991, HTV), Jane Eyre seven times (1946, 1956, 1963, 1973, 1983, 1997, 2006 - all BBC except 1997, LWT).

iv BBC Television had previously mounted The Cherry Orchard twice: 20 March 1947 and 5 January 1958 (Television World Theatre). Neither production survives.

$v$ Because of the lack of documentation for the earlier productions and the extensive accounts about the final production, the section detailing the 1981 production context is longer than those for 1962 and 1971.

vi 'Notes on The Cherry Orchard', reprinted in A Whore's Profession (London: Faber \& Faber, 1994, pp.192-7).

vii Ibid, p.193.

viii World Theatre: Brand (BBC Television, 11 August 1959), originally performed at the Lyric Theatre, Hammersmith. I have written an extensive article about this 
production - http://screenplaystv.wordpress.com/2012/01/27/world-theatrebrand-bbc-1959/

ix Kitchen, Lawrence, Mid-Century Drama, London: Faber, 1960, p.138.

x Anon, 'Uneasy Compromise on Chekhov', Times, 15 December 1961, p.16.

xi Ibid.

xii Ibid.

xiii These performance decisions appear to be carried over from the theatrical version. Reviewing the Aldwych production in the Sunday Times Harold Hobson praised "the blanched, drawn pain of Dorothy Tutin's Varya" for conveying "part of the feckless, insecure happiness and the aching sadness of Chekhov's temperament" 'Chekhov and the Old Man', 17 December 1961, p.27).

xiv Wiggin, Maurice, 'The Young Men Get Desperate', Sunday Times, 15 April 1962, p.48.

xv The eight plays in the 1971-2 run of Play of the Month are representative of the series' classical repertory; Shakespeare (twice), Moliere, Wilde, Chekhov, Tennessee Williams, an adaptation of James Joyce and a new play by Ronald Eyre about Rasputin.

xvi 1970 BBC versions of Three Sisters and Uncle Vanya both survive in their original colour versions, and help one to gain an impression of what The Cherry Orchard must originally have looked like.

xvii Daily Mail critic Peter Black described the effect: "Nataska (sic) Kroll's designs used one exterior set and a single huge and complex interior of rooms, among which director Frederick (sic) Messina's cameras prowled like one more uneasy guest in the doomed household" ('Peter Black on the weekend's TV', 20 December 1971, p.14).

xviii BBC WAC VR/71/554.

xix Buckley, Leonard, 'Chekhov seen plain', Times, 20 December 1971, p.9.

$\mathrm{xx}$ This move between theatre and television production can also be seen in David Jones' move from the artistic directorship of the Royal Court Theatre to BBC producer of Play of The Month in 1977.

xxi Poole, Mike \& Wyver, John, Powerplays: Trevor Griffiths in Television, London: BFI, 1984, p.155-6.

xxii Ibid, p.156.

xxiii Ibid, p.157.

xxiv Griffiths, Trevor, 'Preface', in The Cherry Orchard (Chekhov, Anton, trans.

Griffiths, Trevor), London: Faber \& Faber, 1989, p.2.

xxv Williams, Raymond, Drama from Ibsen to Brecht, London: Pelican, 1973, p.109. 
xxvi Griffiths quoted in Gilbert, W. Stephen, 'Closed Circuits', The Guardian, 17 October 1981.

xxvii Allen, David, 'The Cherry Orchard': a new English version by Trevor Griffiths), in Chekhov on the British Stage (ed. Miles, Patrick), Cambridge: Cambridge University Press, 1993, p.161.

xxviii Ibid, p. 156, Poole and Wyver, 1984, p.155.

Biography: Billy Smart currently works as Research Officer on the AHRC-funded 'Forgotten British Television Drama, 1946-82' at Royal Holloway, and from 2010 to 2013 worked on the 'Spaces of Television: Production, Site and Style' project at the University of Reading. He is joint author with Leah Panos of Space and Place in 1970s Television Studio Drama, published by Palgrave Macmillan. Work has included studies of the role of the director, representations of lesbianism in early British TV drama, the changing visual form of soap opera and how the theatrical conventions of Shakespeare, Brecht, Galsworthy and J.B Priestley were altered by studio practice when adapted for television. 